\title{
Reconciliation as narrative: Witnessing against a too easy and a too difficult reconciliation
}

N Botha

(University of South Africa)

\section{ABSTRACT \\ Reconciliation as narrative: Witnessing against a too easy and a too difficult reconciliation}

After the dawn of democracy in South Africa in 1994 diverse paradigms on reconciliation have appeared on the scene. In this article these paradigms are not discredited so much for being downright unproductive, but they are found to be either too prescriptive as is the case with the TRC or too limited as is the case with the three paradigms of which mere sketches are offered.

The main thrust of the article is a proposal on developing reconciliation as narrative in contradistinction to a dogmatic, technical approach to reconciliation as something to be organised, to be prescribed and engineered. The basic thesis of the article is that narrative can potentially create vast space for story-telling and for many more voices to be heard on the issue of reconciliation. The notion of narrative is advanced as a serious academic category and not an intellectual fad. A further issue is illustrating how issues like remembering, forgiveness and justice need to be brought into discourse with reconciliation.

\section{INTRODUCTION}

There are at least two extremes on reconciliation in South African society which renders the search for a sustainable and lasting reconciliation very difficult if not impossible. These extremes could be described in simple terms as a reconciliation that is projected to be too easy on the one hand and one that is too difficult on the other hand. The trickiness about both is that they cannot simply be regarded as downright unproductive, because they both contain elements of reconciliation or suggestions to that effect which cannot simply be discarded. It would perhaps be safer to say that these are very genuine proposals on reconciliation which have, however, been exposed by life itself in South Africa as too reductionist. Paradigms on reconciliation offered to South Africans since 1994 have been greatly unnerved by persistent poverty, unemployment, violent crime and a number of very nasty racist and xenophobia incidents. The 
point might be illustrated by some of the examples that will pass the revue below.

\subsection{Reconciliation made easy}

What follows is a very broad description of what could be perceived as a reconciliation that is slightly too easy in the historical situation of South Africa. Well meaning and in some instances very noble proposals on reconciliation, but slightly too reductionist to bring about a sustainable and lasting peace. Mere sketches can be offered.

The first example is about what will be called here in very general terms, the Mandela paradigm. The role he played in averting a potentially full scale civil war by negotiating with the Apartheid regime, in particular the National Party and eventually also with the army generals, is well documented. Furthermore, the remarkable display of lack of bitterness and sense of forgiveness and reconciliation has undoubtedly created an atmosphere in the country in the mid - and late nineteen nineties that was quite conducive to genuine reconciliation. The Mandela paradigm, however, came at a huge price for the very victims of Apartheid, namely the poorest of the poor. Or stated differently as Maluleke (1997a:63) does, “...there is a sense in which the example of the benevolent, non-bitter and smiling Nelson Mandela is thrust at angry and hungry South Africans as the example to follow”. An unintended consequence of the Mandela approach was that people seemingly thought that as long as we feel good about one another, as long as we are not at one another's throat, as long as white people do not have to suffer the revenge of black victims of Apartheid, reconciliation would have been achieved. Sooka (2006), a former commissioner of the Truth and Reconciliation Commission (TRC) suggests in strong prophetic terms that justice or in particular justice to the poor has been compromised greatly for the sake of a prescriptive reconciliation. At numerous occasions, in interviews and presentations Sooka (2005; 2006; 2007) follows through on her insistence on justice as a prerequisite for peace, weighing the achievements of the TRC against the objective realities of poverty and want in the country. In speaking to the Nepali Times and in responding to the question: “And reconciliation? When does that come in?" she says:

Reconciliation is necessary on the path to peace. The question here is not just peace, but long-term sustainable peace. And you cannot establish this without full justice. 
Unjust peace is always ad hoc which can bring a different side-effect in society (Sooka 2007).

The Mandela paradigm is an almost perfect illustration of the point made previously that it cannot simply be regarded as unproductive and yet it is the kind of reconciliation which, much as the integrity of Mandela is not questioned, does not deliver to the poor or is it safer to say that in the space of fourteen years there is not enough visible improvement in the situation of the poor. Also, in a very tragic manner violent crime which is related, albeit not entirely, to the prevailing socio-economic inequalities in the country, has exposed the myth of a reconciliation which is slightly too easy. Blatant incidents of racism and the most horrific xenophobia attacks the country has ever seen, have had a compounding and aggravating effect.

Let us look at another example, namely the manner in which secular prophets in South Africa have declared a secular reconciliation. The word secular is here used in the modernist sense of a dichotomy between secular and profane. The issue here is that some politicians like Mbeki and some palace or court intellectuals like Gerwel, have said openly that the issue of reconciliation is not a spiritual, Biblical or theological issue, but a secular issue in the sense that political reconciliation as a product of the negotiated settlement and the TRC process, has been achieved. This is but one of numerous illustrations in South Africa since 1994 where the modernist dichotomisation of issues has almost been perfected. Boesak (2005) interrogates this position critically in his book titled Tenderness of Conscience.

A fundamental deficit of the type of reconciliation advanced by secular prophets is that it is an imposition. It is imposing an elitist reconciliation or a bourgeois reconciliation on others who do not see the logic and the sense of such reconciliation, leave alone not benefiting from it at all. In the South African context an elitist reconciliation refers to the settlement which came about between the chosen few from different political parties, in particular the current ruling party, the African National Congress (ANC) and the former ruling party of the Apartheid regime, the National Party. An elitist reconciliation tends to be extremely hegemonic and manipulative in the following sense. At best those who dare to interrogate secular reconciliation without necessarily questioning the fact that national 
liberation had indeed been achieved in 1994, are labelled as leftists or socialists and at worse they are accused of not being able to undergo a shift in mindset since they are stuck in Apartheid, not to neglect the accusation of being bitter and unforgiving.

A third example is reconciliation as feet washing, relating to a gesture by Vlok, former minister of Police in the Apartheid regime, in ascending upon the Union Buildings in Pretoria to wash the feet of Chikane, currently Director General in the Presidency of the Republic of South Africa. Chikane was chosen for having been the target of a very nasty poisoning plot in the mid nineteen eighties. The ritual has of course also been extended to a group of women in the Mamelodi township who suffered the fate of their children disappearing without a trace. The incident of the feet washing was very widely covered in the South African and international media. Here mention will be made of an interface with Vlok in a very narrow context with a relatively small audience at the annual congress of the Southern African Missiological Society (SAMS) in January 2007 in the Faculty of Theology at the University of Pretoria. For the purposes of this article it is perhaps important to mention that the congress host, Meiring, was instrumental in getting Vlok to the congress. To prolong the biographical note slightly, it should be said to the honour of Meiring that he has always played a major role in bringing people together to talk to one another in their quest for reconciliation. In this particular instance the idea was to facilitate some interaction between Vlok and Lapsley, the latter having been seriously injured in a letter bomb attack on the eve of the arrival of democracy in South Africa, as late as the early nineteen nineties. In brief, the biggest deficit of the Vlok-Lapsley encounter is that ironically it never happened. A golden opportunity was squandered to face a most obvious victim of Apartheid violence, to apologise and to ask for forgiveness. This illustrates an important issue, namely that as much as the integrity of the feet washing gesture should not be questioned, there are too many unresolved issues and unanswered questions around accountability and disclosure for the Vlok paradigm to potentially bring about a lasting reconciliation.

\subsection{Reconciliation made difficult}

In very broad terms a reconciliation in South Africa which is too complicated to achieve could hypothetically be described as follows. 
Only when all of the violent crime stops, only when all of the poverty is eradicated and the unemployment rate brought down dramatically, only when the land question is resolved completely, only when all those who benefited from Apartheid start confessing and apologising one by one, only then will there be genuine reconciliation in South Africa.

Random examples of little statements and analyses which justified as they might be, renders reconciliation extremely difficult.

\section{STATEMENT OF PROBLEM}

These illustrations are pressed into service to arrive at a broad statement of the problem looked at in this article. Once again, the issue is not that nobody is working for reconciliation in South Africa. In fact, the negotiated political settlement of the nineteen nineties and the ensuing TRC process were, barring all of the expediencies and ploys, genuine efforts to find reconciliation. The fundamental problem seems to be, however, that all of the attempts at achieving reconciliation are at best too fragmented, not keeping in creative tension or integrating the indispensable issues of truth, justice, forgiveness and reconciliation. Others may want to add more. At worst reconciliation has become a very lucrative enterprise, so it appears, for those who have benefited greatly since 1994, either in terms of political or economic power. The more benevolent and forgiving they appear to be, the greater the reward.

\section{RESEARCH QUESTION}

In attempting to advance the research question of this study, one must perhaps clarify the issue that it is not a revisiting of the TRC, it is not a critique of the TRC by looking at diverse aspects of the process in detail. Studies like that have been undertaken by numerous others in diverse fields of study. In Theology nobody else has interrogated the TRC the way Maluleke (1997a; 1997b) does. Meiring (2002a; 2002b; 2002c; 2004; 2006) himself has written extensively on reconciliation with particular reference to the work of the TRC.

The basic research question here is whether the notion of a narrative reconciliation where space is created to keep in creative tension or to integrate the issues of knowledge, acknowledgement, accountability (Sooka 2005), forgiveness, justice and reconciliation, will not give greater impetus to the quest for genuine and lasting 
reconciliation in South Africa. Put slightly different, the plea for a narrative approach in reconciliation is a plea for keeping together issues in the quest for reconciliation rather than dichotomising them. Also, it is a plea for an approach that goes beyond dogmatic and technical definitions to a situation where South Africans will begin to converse about issues and by so doing develop a more praxiological understanding than a purely rational or theoretical understanding.

\section{OBJECTIVES}

Emanating from the basic research question are the following objectives:

- Advancing the case for a narrative reconciliation, albeit provisionally and in terms of a few broad strokes;

- Illustrating the integration between diverse aspects and reconciliation, for purposes of this study in particular the dialectic between remembering, forgiveness and social justice and reconciliation. The relationship between justice and reconciliation will be treated more extensively than the former two.

\section{ORGANISATION}

Based on the above objectives, the study proceeds in a straightforward manner and is organised as follows. First, some broad contours of a narrative reconciliation will be offered. Two extremes are avoided as much as possible, i.e. using the notion of a narrative reconciliation in a very general and shallow way so that it becomes nothing more than a fad. That is the one extreme. The other is to indulge in a heavy philosophical discussion on epistemology which in itself might be interesting, but not functional for purposes of this study. This is not to deny at all that the use of the concept of narrative, is in itself already indicating a particular epistemological understanding (Hauerwas \& Jones 1989). Second, illustrations are offered on the interconnection between reconciliation and remembering, forgiveness and in particular justice. Third, the study is concluded by a brief biographical note in which Meiring is identified as the story-telling reconciler or reconciling story-teller.

\section{A NARRATIVE RECONCILIATION}

Is the concept narrative self-explanatory? More specifically, can it be taken for granted that the notion of a narrative reconciliation will be 
well understood without further reference? In an important publication titled Towards an African Narrative Theology by Healey and Sybertz (1996) there seems to be an underlying assumption that the concept narrative is either self-explanatory or to be taken for granted since one will look in vain for any definition whatsoever on reconciliation in the book itself. Or is the definition or method revealed by the unfolding story? Put differently, does the explanation of narrative lie in the telling of the story itself? In introducing the concept of a Narrative Missiology, Balcomb (2008) presses a number of case studies from the Eastern Cape frontier into service, tracing the particular historical-cultural background to show, one supposes, that narrative is not unhistorical, but he does not justify the use of the concept at all.

Is the concept of narrative taken for granted too much in Africa, even in quite serious studies like the two mentioned here? One supposes that trying to hide behind Africa's oral tradition will not necessarily salvage the situation since the oral tradition itself has been developed into a respected academic category in terms of its theoretical grounding.

\subsection{Narrative as serious intellectual and academic category}

Without fear of contradiction Ricoeur (3 volumes on Time and Narrative from 1990) could be regarded as the father of narrative in the twentieth century in the fields of philosophy and theology anyway. In his monumental three volumes on Time and Narrative he distinguishes between cosmological time and phenomenological time. The former refers to time in terms of linear succession and the latter is time as past, present and future (Atkins 2006 in The Internet Encyclopedia of Philosophy). Ricoeur introduces the interesting concept of "human time" which in his understanding (Atkins 2006) integrates cosmological and phenomenological time. He shows that the only possible manner of understanding human existence is to invoke a narrative model. The fact that time as linear succession and time as past, present and future are not mutually exclusive or to be construed in dualistic terms, only makes sense if mediated by narrative. It is for that reason that the notion of emplotment plays such an important role in the philosophical constructs of Ricoeur. Atkins (2006) argues that emplotment as it functions in the philosophy of Ricoeur can potentially "bring diverse elements of a situation into an imaginative order". Atkins goes on to argue that the 
linear chronology of emplotment is able to represent different experiences of time. In Villela-Petit's (2007) understanding:

Narratives encode, and so preserve, the memory of what deserves to be remembered or, on the contrary, of what is so awful and ignominious in the lives of human beings that forgetfulness would be like a second death for the victims.

Nowhere else, the past slightly more than two decades or so, is the suggestion that a narrative approach is not an epistemological or methodological cop-out, worked out more profoundly than in the publication of Hauerwas and Jones (1989) entitled Why Narrative? Readings in Narrative Theology. The contributions lined up in the book show the names of Niebuhr, Frei, Crites and McIntyre to mention just a few. All of these have worked out painstakingly an understanding of narrative that debunks any notion of narrative being an intellectual fad. A further issue in the publication is the great diversity facilitated by narrative, showing that a narrative approach is not a way of bringing everybody in line, but rather a manner, a method, an epistemology which opens up space for more stories to be told, more voices to be heard.

For Hauerwas (1983; 1989) the embarkation on a journey with narrative is to be traced back to the nineteen eighties. In the earlier publication The Peaceable Kingdom, he develops interesting ideas in particular on the "Narrative Character of Christian Convictions". In summary, Hauerwas (1983:24-29) contradicts notions of Christian convictions being narrative only accidentally, stories being only for children and therefore adults will be looking for a substantiation of truth apart from the story. He also debunks the assocciation of stories and narratives with fiction, concluding:

I think this is a dire misreading of the narrative character of Christian convictions. My contention is that the narrative mode is neither incidental nor accidental to Christian belief. There is no more fundamental way to talk of God than in story. The fact that we come to know God through the recounting of the story of Israel and the life of Jesus is decisive for our truthful understanding for the kind of God we worship as well as the world in which we exist. Put directly, the narrative character of our knowledge of God, the self, and the world is a reality- 
making claim that the world and our existence in it are God's creations; our lives, and indeed, the existence of the universe are but contingent realities.

For purposes of this study the distinction he draws between narrative and doctrine is incisive. If understood correctly, Hauerwas seems to suggest that doctrines have no life in and of themselves. They only make sense insofar as they serve as the outline of the story and such they are handy tools helping us to tell the story better. For Hauerwas Christian existence can only be explicated narratively in three main areas. First, our own existence and that of the world as creatures can only be mediated by narrative. Second, narrative is the characteristic form of our awareness of ourselves and third, God has revealed Himself narratively as historical being in the history of Israel and in the life of Jesus. Lucie-Smith (2007) equally makes an overwhelming contribution to the theoretical understanding of narrative with his introduction of three narrative typologies. He offers a very insightful distinction between different models of narrative. He differentiates between narrative as a closed system referring to a very particular setting, narrative as slightly more open and permeable and thirdly, narrative as infinitely open in terms of an infinite horizon.

Much as the search for reconciliation in South Africa refers to a very specific historical situation, it will be argued that there is a need for developing Lucie-Smith's third type of narrative which is imaginative, creative, innovative and for that reason infinitely open in its potential to create new meaning in the country.

Further illustrations of a very productive use of narrative are shown by its implementation in works with ageing holocaust survivors (Barron and Climans 2001), preaching (Driscoll 2007) and congregational pastoral care (Walker-Jones and Hester 2007), to mention a few which must suffice for the discussion here. Numerous elements could be drawn from the way in which narrative is used and understood in the areas mentioned. In reference, for example, to the narrative approach in working with holocaust survivors, Barron and Climans (2001) assert that:

A narrative frame provides a paradigm shift away from a pathologizing approach to viewing survivors and their offspring...takes the focus away from the individual and 
positions the survivor and the events that they endured within a social and historical contextual view.

They go on to show how for holocaust survivors continuity and meaning, a strong sense of self and of well being are created. In the process content and facts, much as they are not unimportant, become far less significant than the process of how survivors say what is said and the underlying meaning of what is said. A few very sharp conclusions drawn by Barron and Climans are first, that history is not a collection of facts to be remembered, but it is constantly created in the telling or retelling of the story. Second, with holocaust survivors narrative facilitates a situation where the issue is more than just the telling of a story, it is also bearing witness and providing a testimony.

On the South African academic scene a narrative approach has been introduced quite productively by the Institute for Therapeutic Development (ITD) run by the Kotzes, forcing notions of "storying" and "re-storying" onto the scene. Of particular importance also is the creation of a Narrative Practical Theology by Müller (2004:293-306) which is social constructionist and post-foundationalist in nature. The research implications of such a creative Practical Theology is that it goes beyond the methodological rigidities of modernist research approaches by picking up stories out of hiv/aids from a very particular context. The research process goes further than a mere recording and describing of stories, in this instance youngsters orphaned and rendered vulnerable by HIV/AIDS, to a level where those telling their stories become co-researchers. The actual creativity of the method is that the stories told inform the creation of a new story or stories and new meaning. This way the stories do not remain closed, nor are they slightly permeable, but they transcend the local community, opening up infinitely new interpretive avenues (Lucie-Smith).

There are instances where the question of reconciliation and the epistemological and creative potential of narrative have been brought into relation with one another expressis verbis. In a most fascinating study on the story of reconciliation between Jacob and Esau, Agyenta (2006) makes out a strong case for narrative as a methodological and interpretive instrument in Biblical scholarship. He shows how a narrative approach makes possible the integration of issues that would otherwise be difficult to achieve: The God 
question in reconciliation, or as he calls it the divine dimension, the issue of those seeking reconciliation facing one another, remembering, the request for and the granting of pardon and the question of justice in the form of reparation, as restorative justice, much as Jacob's approach was flawed in putting the cart before the horses.

Villa Vicencio (Baum and Wells 1997:30-42) draws from a conversation with Kuzwayo, author of Call Me Woman quoting her as saying:

If you cannot understand my story, you do not accept me as your neighbor.

For that reason Kuzwayo, according to Villa Vicencio, insists on more stories being told irrespective of how painful such stories sometimes might be. For her stories are a learning curve for loving each other, for developing understanding, forgiving and a greater understanding of someone else's perspective. Indeed, as Villa Vicencio works out, stories have an infinite potential to broaden the scope, and by so doing to expand the interpretive possibilities, and by so doing to open up ever new avenues of meaning and understanding.

A very fine example of marrying narrative with reconciliation is found with Schreiter (1992) who distinguishes between the narrative of the lie and a redemptive narrative, showing how these are not only diametrically opposed to one another, but also in constant battle with each other. Schreiter (1992:18-39) defines clearly what reconciliation is not. If he is understood correctly one could say that the three elements he identifies are not to be part of any narrative on reconciliation. These are the issues of a hasty peace, regarding reconciliation as a substitute for liberation and seeing reconciliation as something to be organised or engineered. In his presentation to the Athens conference of the WCC on mission, Schreiter (2008:213-219) strongly advances the idea that reconciliation is a new paradigm in mission. A particular issue to be highlighted here perhaps is his interpretation of what he sees to be the process of reconciliation. Feeding into the basic argument of the study, he shows how different issues should be kept together in the search for reconciliation: truth-telling, justice in its diverse modes as punitive, restorative and distributive justice and rebuilding of 
relationships of which the healing of memories would be an indispensable dimension.

Schreiter's thoughts are very fruitful in exposing the new forms of Church theology in South Africa around the question of reconciliation. Quite often churches join uncritically in the campaign against violent crime or the reinstatement of the death penalty, refusing to grapple with the complex of factors informing crime in South Africa. Lip service is paid to reconciliation by either tolerating and perpetuating racism, sexism and classism in its own midst or by not bringing important issues like justice and sustainable economic development into play in what the church teaches. A cheap reconciliation is sometimes also advanced by uncritically buying into notions of development and reconstruction and by discarding the notion of liberation too easily.

\subsection{Towards reconciliation as narrative}

Once again, the present study is not a description, analysis or evaluation of the TRC. However, not by the longest stretch of the imagination can any South African deny that the TRC has been imposed as a very particular paradigm of reconciliation. Petrovic (2003) in showing how TRC's are an attempt to achieve modernisation and to gain the recognition of the international community, also exposes the very dangerous potential of TRC's to fix memories and to construct the past in a very specific, prescribed and incontestable way. A small illustration in reference to the South African TRC must suffice.

When my wife and I were called by the TRC to make statements on the assassination of her brother, Leon Lionel Meyer and his wife, Jacqueline Quinn, in a raid by Vlakplaas commander, Eugene De Kock and his hit squad in December 1985, we were struck by the slight rigidity of the format of the statement. We thought, perhaps naively so, that we would be given an opportunity to tell our own stories, not so much in wanting the perpetrators to be exposed and to be brought to book in terms of retributive justice, but more to narrate our own stories about a prophet, a visionary who has died much too young. His marriage in Lesotho to Jacqueline Quinn where they were based was perhaps symbolically an indication that his struggle was not against white people, but against the heinous system of apartheid. We wanted to highlight his bravery and his dreams of a South Africa that will be genuinely democratic, non- 
racist and non-sexist. We were shocked at the TRC hearing in 1997 where both of us appeared, to see the mistakes in the statements we made since we were not given a chance to effect any corrections ourselves. The issue is simply that the TRC was not careful enough in creating space for people to tell their stories in their own terms and understanding. The shock was compounded at the amnesty hearing of De Kock and others, not because of anything that the latter said or did or twisted or remained silent about. No, the problem was with one of the presiding judges, Pillay, who interrupted witnesses, including myself, when he thought that they were NOT conforming to or complying with the constructions of the TRC. I was interrupted for remotely suggesting that the struggle continues. Clearly what the judge wanted to hear was an unequivocal commitment to reconciliation irrespective of definition. This has been a slightly traumatic experience during 2000. What is the issue at play here? In the context of the present study: the narrative space created by the TRC was polluted by a very strange nervousness, a reactionary and manipulative atmosphere which made the telling of stories in the terms of the narrators themselves, quite difficult. This is not to detract from the experience of quite a number of the more than twenty thousand witnesses before the TRC who found, one way or another, that the appearance before the TRC has indeed brought some relief.

There is a sense in which well meaning and indeed excellent dogmatic and technical theological constructions on reconciliation are experienced as impositions and consequently as impediments to reconciliation. Is there a difference between constructing a doctrine of reconciliation from the Bible and speaking of the story or stories of reconciliation in the Bible? Schreiter (1992) has married the notions of narrative and reconciliation in a rather convincing manner. In the world context of violence perpetrated against one another, between individuals, groups and countries, Schreiter shows how the narrative of the lie and a redemptive narrative are diametrically opposed to one another. In the report of the World Council of Churches (WCC) Conference on World Mission and Evangelism in Athens, the issue of a narrative reconciliation is put in very striking and simultaneously very simple terms:

The Bible is full of stories of reconciliation. The family stories of Jacob and Esau (Gen 25:19-33:20), or of Joseph and his brothers 
(Gen 37-45) are examples of interpersonal - and perhaps also communal - conflicts. They also

illustrate the power of reconciling attitudes of people who try to solve strife, enmity, and experiences or perceptions of injustice through negotiations, repentance, forgiveness and searching for a common basis and shared future.

Reconciliation is thus very much a theme in the biblical narratives and in the liturgical language of Israel (Matthey 2008:71).

Still within the framework of what is conceptualised as Mission as Ministry of Reconciliation in the report, the integration of narrative and reconciliation finds repetition in reference to the story of Jesus Christ in particular and the reconciling work of God in general. The report states:

The Christian narrative of reconciliation is thus based on and centred in the story of the incarnation, passion, death, resurrection and ascension of Jesus Christ. The messianic ministry of Jesus of Nazareth links his suffering with the suffering of all humanity, and is therefore an expression of the deep solidarity of God with an agonized, fragmented and tortured world. The cross is, at the same time, an expression of the divine protest against this suffering, for Jesus of Nazareth suffered as the innocent victim (Matthey 2008:73).

If it is not too much of a tautology, the story of Jesus can in a sense only be communicated and carried forward in narrative mode, particularly his story of reconciliation. This is so, because the narrative of the Nazarene transcends all manner of dogmatic, technical and exegetical presupposition. Indeed, it is only "through the Holy Spirit that human beings are empowered to share in the narrative of God reconciling the world in Jesus Christ” (Matthey 2008:73).

Based on the very brief illustration above with reference to the TRC and the way in which reconciliation surfaces as narrative in the Bible, the following provisional construction on a narrative reconciliation in South Africa could be made. A South African narrative reconciliation begins where South Africans find the free space beyond any form of political and theological engineering to 
bring their own stories from the past, their experiences presently and their dreams and hopes for the future into discourse with the Biblical narrative of reconciliation. South Africans should be afforded an opportunity to spend "human time" (Ricoeur) with one another if indeed "human time is the time of our life stories or histories" (Villela-Petit 2007). Human time, Villela-Petit goes on to say, as distinguished from inner (each consciousness) time and cosmic time "calls attention to time of human action and suffering. Only through the act of telling a story can this time acquire a figure and, in so doing, be preserved from oblivion as "time passes by".

\section{ON INTEGRATION IN NARRATIVE RECONCILIA- TION}

Retrospectively one of the biggest deficits of the TRC perhaps, is the unintentional dichotomisation of issues. Winslow (1997) draws attention to the manner in which the issues of truth telling, redress and amnesty have been separated from one another and allocated to separate commissions. As such the TRC, once again unintentionally, as a mechanism that was supposed to put South Africans on "The Road to Reconciliation" is an almost perfect example of how instead of keeping issues together in creative tension, they were separated from one another. For what purposes? A more narrative approach in trying to integrate the issues of disclosure, redress and amnesty, however complex these issues are, might have been more productive in opening up the road to reconciliation.

Extremely complex and difficult as the question might be, the proposal here is that for genuine reconciliation to get underway - as a narrative way of speaking in contradistinction to speaking of a successful reconciliation - it should constantly be integrated into issues of accountability, forgiveness, healing and in particular justice, to mention only these for now. The question of integration could be treated by making a careful selection of issues to be integrated into reconciliation or vice versa or by pressing a number of illustrations into service. The study proceeds by using the latter strategy, highlighting in particular the issues of remembering, forgiveness and justice in relation to reconciliation.

\subsection{Remembering and reconciliation}

Perhaps one of the most difficult issues in South Africa impacting on the quest for reconciliation, is the question of dealing with the past (Meiring 2006). Two extremes seem to be occupying the minds of 
South Africans. On the one hand there is the notion of "let bygones be bygones" and on the other hand there is the tendency to constantly dwell in the past and to use Apartheid as an absolute frame of reference. The grave danger of the former notion is a type of amnesia and denialism which is deadly to any search for reconciliation since people will not know what to reconcile about. Conversely, the danger of being stuck in Apartheid is that generations to come can potentially be turned into slaves of apartheid.

Remembering is indeed a complex issue. No wonder that Müller-Fahrenholz (1997:33-39) speaks of "the art of remembering". In drawing from the Jewish proverb, "Forgetting prolongs captivity. Remembering is the secret of redemption", he works out the distinct difference between captive remembering and redemptive remembering. Much as forgiveness will be highlighted separately as one of the issues to be brought into discourse with reconciliation in the study, it is touched upon here since MüllerFahrenholz deals with the relationship between forgiveness and remembering. In almost poetic terms he writes that "forgiveness leads those involved through the narrow gates of pain into the blissful discovery of mutual liberation. A healing takes place which sets the stage for renewed relationships built on trust and gratitude”. But what about remembering? He is quick to point out that the past cannot simply be forgotten. If he is interpreted correctly the issue of remembering is not so much the "what" of remembering, but the "how". In his understanding those who have found deliverance through forgiveness, emerge "with a new and profound awareness of the human condition”. There is a new vocabulary, a new language consisting of words like awareness, understanding, sensitivity and empathy. This according to Müller-Fahrenholz goes beyond forgetting or suppressing past hurts or the harbouring of animosities and thoughts of vengeance. He sharply draws from the etymological roots of the word "remembering" which in its original sense means "bringing together the members and pieces of something that was once complete, a joining together of what has been severed, a making whole of that which is broken, a restoring of the distorted".

Schreiter (1992:38-39) shows in an insightful way the connection between remembering and identity. In the context of violence and what Schreiter sees as the battle between the narrative of the lie and a redeeming narrative, he identifies "a reconstruction 
of memory” as preceding the ability to trust. In connecting memory to identity he goes on to assert:

Memory is the principal repository of our identity. We turn to memory to know who we have been both as individuals and as a people. We add to memory as we gain experience and insight; we adjust our memories in light of those same experiences and insight. Loss of memory is loss of identity.

The very same argument on the relationship between memory and identity is advanced by Santer (Falconer 1988:128) in reference to the Northern Ireland context. In responding to the question Why is the category of "memory" so important? He contends:

Memory is important because of the crucial role it plays in relation to our sense of identity. A person with amnesia has lost his identity, except what can be reconstructed from other peoples' researches and memories. It is through our memories, through our recollection of the past, and through what others have told us about the past, that we identify ourselves as who we are.

Harris (Falconer 1988: 39-40), in dealing with the same context as Santer shows wariness of a recollection of the past which feeds into the modernist need for rational constructs which in his understanding would result in "descriptions which dissociate people from the "event". For Harris the reintroduction of remembering into the story, is more than the recall of information. He draws an interesting distinction between what he calls "historical revisionism" and the "reconciliation of people, subjects as embodied experience". Feeding into the main thrust of this study is the inference by Harris that "what we have lost is the experience of constructing narratives, as a shared practice in the 'present'”.

A very tragic consequence of the South African tendency to run away from the past, is indeed a serious loss of identity. The almost uniquely South African irony is that the more South Africans try not to deal with the past the more our lives are stamped by the very violence of the past in the form of violent crime, racist attacks and the horrific xenophobia attacks witnessed in the country during May 2008. There is a real need in South Africa not so much for the type of truth telling envisaged by the TRC, but more for a construction of narratives that would create space for people to be at ease with 
themselves and with others. More importantly, reconciliation should be understood by South Africans more in terms of listening to diverse voices than to force the issue of the own story.

However, Schreiter (1992:38) hurries to point out that a reconstruction of memory is not simply the retrieval of memory. He suggests that to overcome the suffering caused by violence, first, the older memory should be disengaged from the acts of violence and second, the burden of trauma it carries should be eased by repeating the narrative of the violence over and over again. Once again, this is exposing a fundamental flaw in the South African quest for reconciliation in that South Africans assume that the less we narrate what happened in the past, the sooner we shall arrive at genuine reconciliation. Nothing could be further from the truth.

\subsection{Forgiveness and reconciliation}

Tutu's (1999) book suggests quite strongly that without forgiveness there is no future. Indeed, the very title of the book says it all: No Future Without Forgiveness. The book is narrative in nature and simply for that reason remains an important source in the ongoing search for reconciliation not only in South Africa, but worldwide. To say that it is narrative in nature does not only refer to the numerous stories told in the book, in chapter 11 in particular, dealing with the difficult issue of forgiveness, stories of Tutu's visits to Rwanda, Ireland, Israel and Palestine are being related. Once again, there is more to narrative than simply telling stories. A major achievement in the book is the manner in which very complex, but related issues are kept in creative tension: confession, forgiveness, reparation and social justice. Retrospectively the question remains whether the whole TRC process should not have been informed more strongly by such integration of issues.

Focussing on the issue of forgiveness, Tutu (1999:218-219) follows a similar pattern as Schreiter (1992:18-39) on reconciliation by showing what forgiveness is not. First, in his understanding, "Forgiving and being reconciled are not about pretending that things are other than they are. It is not patting one another on the back and turning a blind eye to the wrong. True reconciliation exposes the awfulness, the abuse, the pain, the degradation, the truth”. Some discourses in South Africa on forgiveness and reconciliation suggest that these and a full disclosure of what happened in the past are mutually exclusive. Second, in Tutu's interpretation, forgetting is not 
a logical consequence of forgiving. The importance of remembering, says Tutu (1999:219) is "so that we should not let such atrocities happen again”. Third, forgiveness is not being sentimental.

Tutu's positive definition of forgiveness is extremely challenging to particularly the victims or let us say those who have been on the receiving end of, in South Africa's case, Apartheid. "Forgiving”, says Tutu (1999:219) "means abandoning your right to pay back the perpetrator in his own coin, but it is a loss which liberates the victim". In answering the question whether the victim's forgiveness depends on the contrition and confession of the perpetrator, Tutu (1999:220) answers:

There is no question that of course, such a confession is a very great help to the one who wants to forgive, but it is not absolutely indispensable (my italics). Jesus did not wait until those who were nailing Him to the cross had asked for forgiveness. He was ready, as they drove in the nails, to pray to his Father to forgive them and He even provided an excuse for what they were doing. If the victim could forgive only when the culprit confessed, then the victim would be locked into the culprit's whim, locked into victimhood, whatever her own attitude or intention” (cf Müller-Fahrenholz 1997 The Art of Forgiveness).

In typical narrative style Tutu goes on to show how the act of forgiveness opens a window on the future, not only for the forgiver, but in particular also for the wrongdoer since forgiveness is a declaration of faith in the capacity of the latter to make a new beginning.

To illustrate the point of Tutu's mindfulness of the importance to keep a number of issues together, one could refer to his awareness of the fact that the disparities between the mainly white rich and mainly black poor in South Africa has placed the whole process of reconciliation in jeopardy. This brings us to the next issue.

\subsection{Justice and reconciliation}

Since the TRC process in South Africa has virtually precluded any form of retributive justice, the issue will not be dealt with here, much as serious texts on former or current situations of conflict where reconciliation is sought after, highlights the importance of 
retributive justice. In the WCC report on the Athens 2005 conference, retributive justice is identified pertinently as part of the "Dynamics of Reconciliation Processes" and is understood as a task of the state in holding wrongdoers accountable for their deeds (Matthey 2008:78-79). The focus here is on constantly bringing discourses on reconciliation and justice into interaction with one another. If it would not be too much of a slogan, the issue is that there can be no reconciliation without justice, alternatively, those wanting reconciliation should work for justice.

Numerous texts on reconciliation show the inextricable link between justice and reconciliation. There is a sense in which the "hasty" reconciliation in South Africa came at a very big price for the poor, namely the postponement of justice. A narrative reconciliation is a reconciliation where the issues of poverty and justice are not so much treated as notions for technical definition, but as metaphors forming the basis for story telling.

Once again the remarkable feature of the book by Tutu is not only that it is written in narrative style, but also that for precisely that reason it has enabled him to keep together in creative discourse the issues of justice and reconciliation. In contending that there is another kind of justice than retributive justice Tutu (1999:51) argues in favour of restorative justice which he regards as "characteristic of traditional African jurisprudence”. In restorative justice, says Tutu, "the central concern is not retribution or punishment but, in the spirit of ubuntu, the healing of breaches, the redressing of imbalances, the restoration of broken relationships". On the issue of the redressing of imbalances the WCC report on the Athens 2005 conference concurs with Tutu in stating that restorative justice has to do with restoring what has been taken wrongfully from victims. This could be done in symbolic form or in the form of reparation or compensation. An important dimension added in the report in dealing with the scope of justice in reconciliation, is that of structural justice "whereby the institutions of society are reformed to prevent instances of injustice from happening in the future" (Matthey 2008:79). Of course the document mentions, albeit very briefly the complex nature of structural justice which in the case of economic justice would necessitate the reform of global trade laws and other mechanisms of trade. The South African narrative on justice ought to be one where the poor are not given false hopes in terms of the ideology of delivery and a better life for all, but where a genuine story is being 
created that change is indeed possible and that their stories of suffering and want, but also of joy, hope and creative ways of alleviating poverty themselves, constitute the essence of a narrative with infinitely new meaning and value.

Other sources on reconciliation follow suit as far as the connection between justice and reconciliation is concerned. Space does not allow for elaboration in any measure so that what follows is nothing more than a brief survey aimed at illustrating how the discourse between justice and reconciliation is found to be important in diverse texts. The somewhat fragmentary impression that this might create is intentional in trying to show how a narrative rather than a dogmatic, foundationalist approach creates more space for more voices. The interesting point that will emerge is that much as the sources cited here are in agreement on the issue of reconciliation with justice, each of them brings their own creative dimension to the discussion.

In a document in which the understanding of Christian mission by the Lutheran World Federation (LWF) gets expounded the notions of transformation, reconciliation and empowerment are brought together (Messenger 2004:32-36). In fact mission is described in metaphorical terms as "Mission as Transformation, Reconciliation and Empowerment". Transformation in particular is then interpreted in relation to justice in the following manner:

Transformation is a continuous process of rejection of that which dehumanises and desecrates life and adherence to that which affirms the sanctity of life and gifts in everyone and promotes peace and justice in society.

In striving towards reconciliation with justice in South Africa it is paramount to contradict the culture of entitlement and forms of corruption which are quite often perpetrated under the guise of transformation. A new narrative needs to be created in which the continued dehumanisation of the poor and the cheapness of life in South African society is strongly resisted.

Wolterstorff (1983:69-72) contends that a more comprehensive vision is needed. In the context of this study the narrative needs to be expanded in terms of its infinitely vast potential to effect the outbreak of genuine reconciliation with peace and justice. Says Wolterstorff that the vision needed is "shalom intertwined with 
justice”. In shalom, according to him, each person enjoys justice and his or her rights. He goes on to argue that shalom is going beyond justice since it touches on our fundamental relationships with God, ourselves, others and nature. Indeed, the quest for reconciliation in South Africa goes beyond the settling of issues related to Apartheid, but extends to a holistic reconciliation of South Africans with God, each other and the living environment.

Looking at other sources in brief, there is a very incisive moment to be found with Shriver (1989:136-150) in reference to the American Civil Rights Movement. He contends that the political struggle for justice in America was simultaneously a struggle for reconciliation between the antagonists. In South Africa, unfortunately this has not been consolidated enough. Retrospectively one can only speculate on what the outcomes of the TRC process would have been, had there been a stronger emphasis on justice and reconciliation rather than truth and reconciliation. Perhaps the struggle hermeneutic should once again be introduced in a more positive sense as a struggle for reconciliation with justice rather than a struggle against.

Another very interesting twist almost in bringing reconciliation into discourse with justice or the other way around, is found in a WCC Faith and Order Document entitled Participating in God's Mission of Reconciliation (2006). In dealing with the "requirements of justice" in reconciliation, the TRC is mentioned and commended for the work it did in healing the wounds caused by apartheid. However, the document proceeds to make the following critical comment in trying to illustrate the important connection between justice and reconciliation:

Notwithstanding this, the TRC has been criticised for providing neither room nor the conditions in which justice is both done, and seen to be done. Some have suggested that the Commission should have addressed the issues of compensation, restoration and restitution. (Faith and Order 2006:50).

A rather helpful aspect of the manner in which the document looks at the issue of justice in relation to reconciliation is by invoking the question of power. A major deficit of the South African narrative or lack thereof on reconciliation is that more often than not discourses on the issue assume that reconciliation is achievable outside the 
context of the prevailing power relationships in the land. What the Faith and Order document shows is that "political power derives its legitimacy from the goal of just relationships. Justice is the norm for creative living in society, irrespective of the particular social and political order" (Faith and Order 2006:51). In dealing critically with the tendency to concentrate power, the document puts the poor at the centre of the discussion on justice and power in relation to reconciliation. In essence the South African narrative on reconciliation is to be informed by the concern for the poor, justice for the poor and a reinvention of the "rights of the poor".

Other very helpful and creative discourses on the linkage between justice and reconciliation are to be found, by way of a few final examples: Roberts (1994:8-20) brings liberation and reconciliation into discourse with one another. De Gruchy 1997:1629) in a contribution with a striking title The Dialectic of Reconciliation, raises the critical issue of solidarity in the search for reconciliation on three levels. First, solidarity as taking sides "with all who remain oppressed in one form or another in a new democratic society and participating with them in their never-ending struggle for justice, human dignity and liberation"; second, defence of human rights; and as a third level of the church's solidarity, its own self-critique.

\section{STORY-TELLING RECONCILER, RECONCILING STORY TELLER}

A very strong element in the preaching, teaching and scholarly work of Meiring has always been the importance of narrative. In reflecting on how best I would want to describe him in terms of his tremendous contribution as pastor, church official, academic and in particular as commissioner of the TRC, I would like to identify him as a storytelling reconciler or reconciling story-teller. Far from suggesting even remotely that he will want to avoid thorny issues, it would be fair to say that he is a peacemaker. Not by ignoring genuine differences of opinion between people, but by engaging such differences with narrative. In constantly searching for stories of hope, be that in the very difficult and protracted unification process in the Dutch Reformed Family of Churches or on issues of race and poverty and of course reconciliation, he is continuously also creating ever new stories. An almost perfect illustration of his approach in reconciliation is the manner in which he begins an article titled Can 
swords be hammered into ploughshares? Reconciliation in PostApartheid South Africa: "Let me take you back to that glorious day in May 1994..." (Meiring 2006). Once again, his narrative inclination does not result in a sidestepping of the issues. On the contrary, he engages them openly, addressing himself to the very difficult issues of dealing with the past, defining reconciliation clearly, truth and reconciliation and justice and reconciliation, calling the latter of them the two sides of a coin. Ultimately the issues are treated in a manner that does not at all feed into despair and pessimism, but hope in the sense of swords being hammered into ploughshares and spears being turned into pruning hooks.

\section{Consulted literature}

Agyenta, A 2006. "To See Your Face is like seeing the Face of God". A narrative Study of the Story of Fraternal Strife Between Jacob and Esau (Genesis 25-33). Unpublished dissertation.

Atkins, K 2006. Paul Ricoeur (1913-2005): http://www. Phillwebb.net/ History/Twentieth Century/ Continental/ Phenomenology/ Ricoeur/Ricoeur htm.l

Balcomb, A 2008. Mission as biography: Case studies from the Eastern Cape frontier. Unpublished paper read at the January 2008 annual congress of the Southern African Missiological Society (SAMS), University of North West, Potchefstroom campus.

Barron, S \& Climans, R 2001. A Narrative Approach to Working with Aging Holocaust Survivors and Their Families Inside the Institution: $h t t p: / / w w w$. baycrest.org/If Not Now/voulme 2 Spring 2001/default 7335 asp.

Baum, G \& Wells, H (eds) 1997. The reconciliation of peoples: challenge to the Churches. Geneva: WCC; Maryknoll, N.Y: Orbis books.

Boesak, A A 2005. The Tenderness of Conscience: African Renaissance and the Spirituality of Politics. Stellenbosch: SUN PRESS.

De Gruchy, J W 1997. The Dialectic of Reconciliation. Church and the Transition to Democracy in South Africa, in Baum, G \& Wells, H (eds) 1997. The reconciliation of peoples: challenge to the Churches. Geneva: WCC; Maryknoll, N.Y: Orbis books, 16-29.

Driscoll, M 2007. Narrative Approach? Will it Preach? http://johnploughman. wordpress.com/2007/05/02/Preach?mark-driscoll-and-narrative-preaching.

Faith and Order Paper 201, 2006. Participating in God's mission of reconciliation: a source for churches in situations of conflict, World Council of Churches.

Falconer, A D (ed) 1988. Reconciling memories. Dublin: The Columbia Press.

Harris, J 1988. Reconciliation as Remembrance in Falconer, A D (ed) 1988. Reconciling memories. Dublin: The Columbia Press, 37-51. 
Hauerwas, S 1983. The Peaceable Kingdom: a primer in Christian Ethics. Notre Dame: University of Notre Dame Press.

Hauerwas, S \& Jones, G (eds) 1989. Why narrative? Readings in narrative theology. Grand Rapids, Mich.: WB Eerdmans.

Healey, J \& Sybertz, D 1996. Towards an African Narrative Theology. Nairobi: Paulines Publications Africa.

Lucie-Smith, A 2007. Narrative Theology and Moral Theology. The Infinite Horizon. Hampshire, England and Burlington USA: Ashgate Publishing Limited.

Maluleke, T S 1997a. Truth, national unity and reconciliation in South Africa: Aspects of an emerging agenda. Missionalia 25(1), April 1997 - 59-86.

-, 1997b. "Dealing lightly with the wound of my people?" The TRC process in theological perspective. Missionalia 25(3), November 1997, 324-343.

Matthey, J 2008. Come Holy Spirit, heal and reconcile! Report of the WCC Conference on World Mission and Evangelism, Athens, Greece, May 2005. Geneva: WCC Publications.

Meiring, P G J 2002a. Truth and Reconciliation. The South African Experience. Expository Times, 114(3), December - 75-80.

-, 2002b. Pastors or lawyers? The role of religion in the South African Truth and Reconciliation Commission process. HTS 58(1), 328-339.

-, 2002c. Leadership for reconciliation: A Truth Commission perspective. Skrif en Kerk 23(3), 719-735.

-, 2004a. Truth and Reconciliation in South Africa: Hindu experiences and concerns. HTS 60 (4), 1383-1398.

-, 2004b. Truth and Reconciliation in South Africa: Jewish voices and perspectives. Verbum et Ecclesia 25(2), 546-567.

-, 2006. Can swords really be hammered into plowshares? Reconciliation in Post-Apartheid South Africa: http://www.ctbi.org.uk/pdf view.php?id=19.

Messenger, J (ed) 2004. Mission in context: transformation, reconciliation, empowerment : an LWF contribution to the understanding and practice of mission/The Lutheran World Federation, Department of Mission and Development.

Müller, J 2004. HIV/AIDS, narrative practical theology, and postfoundationalism: The emergence of a new story. HTS. 60(1 \& 2), 293-306.

Müller-Fahrenholz, G 1997. The art of forgiveness: theological reflections on healing and reconciliation. Geneva: WCC Publications.

Petrovic, M 2003. The practice of justice and understandings of truth. Truth and Reconciliation Commissions: http://www.eurozine.com/pdf/2003-12-02petrovic-en.pdf.

Ricoeur, P 1990. Time and Narrative. Volumes 1, 2 and 3. Chicago: University of Chicago Press. 
Roberts, D J 1994. Liberation and reconciliation: a Black Theology. Maryknoll, N.Y.: Orbis books.

Santer, M 1988. The Reconciliation of Memories in Falconer, A D (ed) 1988. Reconciling memories. Dublin: The Columbia Press, 128-132.

Schreiter, R J 2008. Reconciliation as a New Paradigm of Mission...in Matthey, $\mathrm{J}$ 2008. Come Holy Spirit, heal and reconcile! Report of the WCC Conference on World Mission and Evangelism, Athens, Greece, May 2005. Geneva: WCC Publications, 213-219.

-, 1992. Reconciliation: Mission and ministry in a changing social order. Maryknoll, N.Y.: Orbis books.

Shriver, D 1989. Forgiveness and the American Blacks. An Irish Quarterly Review 78(310), 136-150.

Sooka, Y 2005. Justice and Reconciliation. Press statement in Berne, Switzerland on 24 February 2005:http://www.apartheidreparations.ch/documents/reparationen/e 0502 Sookapress.pdf.

-, 2006. Forum discussion at a conference on Reconciliation hosted by the South African Council of Churches, held at the University of South Africa, October 2006.

-, 2007. Justice as a pre-requisite for peace. Interview with the Nepali Times: http://www.nepalitimes.com/issue/363/interview/13897.

Tutu, DM 1999. No Future Without Forgiveness. London: Rider.

Villa-Vicencio, C 1997. Telling One Another Stories. Toward a Theology of Reconciliation...in Baum, G \& Wells, $\mathrm{H}$ (eds) 1997. The reconciliation of peoples: challenge to the Churches. Geneva: WCC; Maryknoll, N.Y: Orbis books, 30-42.

Villela-Petit, M 2007. Narrative Identity and Ipseity by Paul Ricoeur. From Ricoeur's "Time and Narrative" to "Oneself as an Other": http://www.theology.ie/thinkers/ricoeur.htm

Walker-Jones, K and Hester, D 2005. A narrative Approach to PastorCongregational relationships: http://www.tripastoralcounseling.org/new pagehtm.

Winslow, T 1997. Reconciliation: The Road to Healing? Collective Good, Individual Harm? Track Two, 6 (3 and 4), December 1997.

Wolterstorff, N 1983. Until justice and peace embrace. Grand Rapids, Mich.: William B Eerdmans. 